This is an electronic reprint of the original article. This reprint may differ from the original in pagination and typographic detail.

Please cite the original version: Luojus, S. \& Kauppinen, S. (2021) The Role of Higher Education Institutes in Public Sector Innovation Ecosystems, INTED2021 Proceedings, pp. 1788-1794. 


\title{
THE ROLE OF HIGHER EDUCATION INSTITUTES IN PUBLIC SECTOR INNOVATION ECOSYSTEMS
}

\author{
Satu Luojus ${ }^{1}$, Sami Kauppinen ${ }^{2}$ \\ 1,2 Laurea University of Applied Sciences (FINLAND)
}

\begin{abstract}
Innovation is important as it enables the bringing of new and fresh things to the market, which challenge old services, products and businesses and thus opens the way for development. Innovation can be regarded as a combination of existing ideas or the generation of new ideas, products and services, or widely viewed as the main driver of growth in contemporary economies. In the era of the knowledge economy, the economic rise of a society is closely linked to its ability to produce, disseminate and apply innovations and to utilize and lead collaborative innovation ecosystems.
\end{abstract}

Network-based co-creation is an attempt at addressing the challenges in public sector innovation, and it has developed into a globally adopted key principle for creating and producing public services. It engages different actors to recognise and solve collaboratively needs and problems pertaining to services and the service ecosystem. Collaborative innovation utilizes the resources and creativity of external networks and communities to strengthen the speed of innovation process and to improve the scope and quality of innovations. Service ecosystems emphasize the idea that co-creation takes place in networks consisting of customers, the public and private sectors, as well as other stakeholders.

Co-creation has mainly been studied from the perspective of customers and companies. In this paper, we examine the perspective of higher education. Thus, the purpose of the paper is to deepen understanding of the role of higher education institutes in the public innovation ecosystem. Drawing upon three workshops, which were attended by the public sector and university representatives, as well as public management literature, the aim of the paper is to outline characteristics for participation of higher education institutes in the public innovation ecosystems.

The results indicate that higher education institutes have a significant role in the public innovation ecosystem as drivers of national competitiveness. In addition to their educational mission, higher education institutes promote regional development by maintaining networks and orchestrating innovation activities in the ecosystem.

Keywords. Higher education, public sector innovation, ecosystems

\section{INTRODUCTION}

The Finnish higher education system has a dual model: universities focus on scientific master's and higher degrees and universities of applied sciences on vocationally oriented higher education on bachelor and master levels. This paper concentrates on the role of higher education institutes in public innovation ecosystems from the perspective of universities of applied sciences' and the EQF7-level education they provide. The University of Applied Sciences Act defines the mission of universities of applied sciences as follows: "1. The mission of universities of applied sciences is to provide higher education for professional expert jobs based on the requirements of working life and its development and on the premises of academic research and academic and artistic education and to support the professional growth of students. 2 . They shall also carry out applied research, development and innovation activities and artistic activities that serve education in universities of applied sciences, promote industry, business and regional development and regenerate the industrial structure of the region. In carrying out their mission, universities of applied sciences shall promote lifelong learning." [1].

The European Qualifications Framework (EQF) is a learning outcomes-based framework for all types of qualifications in Europe that serves as a translation tool between different national qualifications frameworks. Master's degrees awarded by universities of applied sciences are equivalent to Master's degrees awarded by universities (EQF7). EQF7 level education emphasizes the knowledge, skills and competencies needed to manage and develop complex, unpredictable operating environments that 
require new strategic approaches. Megatrends that anticipate changes in the operating environment (see e.g. Sitra 2020) are drivers of future changes and affect all sectors of society and the economy.

The role of universities and research institutes in national innovation ecosystems has been identified and acknowledged. As relatively new arrivals in the Finnish higher education system, the role of universities of applied sciences in the national innovation ecosystem is not yet well established. On the other hand, the three tasks of the universities of applied sciences presented above require them to participate in regional development and to collaborate closely with various actors in society. Innovation ecosystems and living labs based on co-creation and organized by the public sector have been increasingly established in recent years and those have become more important elements in the development of public sector services. These new environments provide virtual and physical platforms for research and development activities and thus a unique opportunity to conduct the mission of the universities of applied sciences.

\section{PUBLIC SECTOR INNOVATION}

Innovation is important as it enables the bringing of new and fresh things to the market, which challenge old services, products and businesses and thus opens the way for development. The OECD's report [2] defines innovation as "the implementation of a new or significantly improved product (good or service), or process, a new marketing method, or a new organisational method in business practices, workplace organisation or external relations" [2, p.16], while Baregheh et al. [3] describe it is a multi-stage process whereby ideas are transformed into products, services or processes. Innovation may describe different types of activities, namely creativity, development, distribution/dissemination and the implementation of new service ideas [4].

As far as public sector innovation is concerned, it is not a new thing: a more systematic innovation policy in the public sector is rather a new area of research that emerged after the millennium change [5]. Demircioglu et al. [6] identify public sector innovation as "comprise new or significant changes to services and goods, operational processes, organizational methods, or the way your organization communicates with users" [6 p.1682].

Three paradigms of public government and governance can be seen in the public sector's history, namely public administration, New Public Management (NPM), and network-based collaborative governance. In the era of public administration, the Weberian concept of government was dominant, in which "politicians are charged with decision making while public employees deliver the public services" [7, p.14] that are "based on a largely legislative, bureaucratic and rule-based order" [8, p. 204]. Later, the NPM trend in the 90' led many governments to implement ideas from business management into the public sector, aiming to enhance its efficiency as a provider of public services and develop further the management skills of public sector managers [7]. However, NPM's business-oriented strategy in the public sector has not entirely been beneficial with regard to public services innovations [9]. Therefore, new approaches have been sought to public sector innovation management and the strong market-driven approach of NPM has later transformed rather into customer-centricity and quality management.

More recent literature emphasizes collaborative forms of governance in networks and partnerships, because the world has become, as Bryson et al. [10, p. 641] describe, "a polycentric, multi-nodal, multi-sector, multi-level, multi-actor, multi-logic, multi-media, multi-practice place characterized by complexity, dynamism, uncertainty and ambiguity in which a wide range of actors are engaged in public value creation and do so in shifting configurations" [10]. Pollitt et al. [11] identify that "governance" emphasizes "partnerships between stakeholders" that "bring different skills and resources to address complex problems" [11, p. 22], such as economic, social and environmental issues. Consequently, the number and diversity of literature related to governance systems of networks and multi-stakeholder co-creation has grown rapidly.

\section{INNOVATION ECOSYSTEMS}

Co-creation within the public sector emphasises the idea that interaction takes place in service ecosystems organised by the public sector. Service ecosystems are described as "relatively selfcontained, self-adjusting systems of resource-integrating actors connected by shared institutional logics and mutual value creation through service exchange" [12]. In service ecosystems, value creation for different actors does not occur in accordance with traditional notions at the end of the 
supply chain, but through every interaction within the network. The companies are e.g. created global ecosystems that seek to promote the development and diffusion of a particular company's technology and related services and applications.

Pinho et al. [13] highlight to concentrate on "a dynamic network view" as it is "needed to be able to comprehend the whole system of service systems" [13, p. 489]. Trischler and Charles [14] suggest "a service ecosystems approach" instead of "the exchange paradigm of marketing" to the public sector. Similarly, Petrescu [15] proposed to combine the service ecosystem approach into the public sector. Consequently, the public management research is recently interested in the systemic approach, which goes beyond the service delivery of a public organization and is based on a wider multi-actor and level ecosystem $[16,17]$. Sørensen et al., $[18$, p. 3] describe that networks empathize "non-hierarchical forms of governance based on negotiated interaction between a plurality of public, semi-public and private actors". Similarly, Huppé et al. [19, p. 24] describe that networks enable external actors "to contribute their unique resources to the generation of creative, collaborative, complex solutions". Emerson et al. [20, p. 18] defines that such a collaborative approach aims to "engage people across the boundaries of public agencies, levels of government, and / or the public, private, and civic spheres to carry out a public purpose that could not otherwise be accomplished." The engaged actors should have "relevant knowledge, ideas and resources or are affected by the problem or the innovative solution." [21, p. 7]. The participants of public sector innovation can be for example citizens, companies, third sector organizations, and/or universities.

The Helsinki Regions in Finland has been actively created an innovation-driven society and innovation ecosystems that aim to "to drive its urban development processes, discovering new evidence-based answers to support the provision of services to its stakeholders, and at the same time learning how to contribute to well being in a world without borders" [22, p. 15]. Raunio et al. [23] have identified three different types of approaches for the public sector to orchestrate innovation: (1) The 'forum' is a well-established approach, which brings together actors with different knowledge and information resources to accelerate innovation. The activity usually takes place in a physical environment. (2) The goal of open and agile pilot environments, which have recently become popular, is to accelerate innovation by involving users more closely to the process. (3) Open innovation platforms, which emphasize the conceptualization, scaling and more systematic transparency, can be seen as the latest approach where the digitalisation has supported these goals. [23].

\section{METHODOLOGY}

Our goal is to deepen the understanding of the co-creation of services within the public sector innovation from the perspective of higher education institutes. We aim to outline the characteristics for participation of higher education institutes in the public sector innovation ecosystems. For this purpose, we have conducted three participative workshops, which were attended by the public sector and university representatives. In the workshops, research material was collected using the design games method. Design games have open tasks that allow the participants to make their own interpretations and find meaningful focus, are engaging, create a relaxed and informal atmosphere that increases creativity and utilise different senses [24]. The research data consists of recordings of the workshops. The analysis of the research data followed the principles and steps of content analysis: transcription, reduction, clustering and abstracting. Content analysis refers to qualitative data reduction and sense-making efforts that take a volume of qualitative material and attempt to identify core meanings [25].

The study was conducted in a Horizon 2020 project called A New Concept of Public Administration Based on Citizen Co-created Mobile Urban Services (WeLive). The aim of the project was to find ways to transform the current administration-centered approach to build public services more into an open and collaborative process that enables easy involvement of citizens, companies, and public administrators. Laurea represented expertise in co-creation research in the WeLive project. 


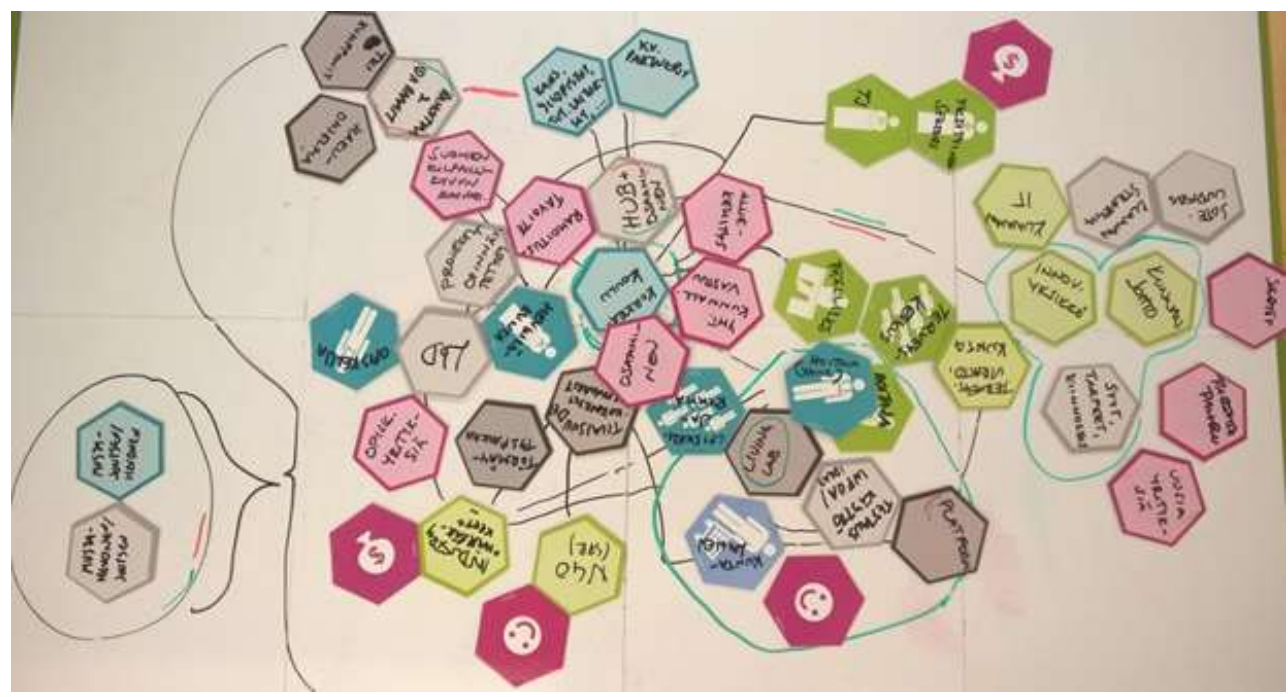

Figure 1. The workshop participants together outlined a new vision of the public sector innovation ecosystem by using a design game.

In particular, we sought to address the following questions from the perspective of higher education institutes that have participated in the public sector innovation ecosystems. What is the role of higher education institutes in services innovation ecosystems organised by the public sector? Which actors are needed and can support the operations of higher education institutes in the public sector innovation ecosystems? What other stakeholders does the innovation involve and what roles do they have in it?

\section{UNIVERSITY OF APPLIED SCIENCES AS AN INNOVATIVE KNOWLEDGE COMMUNITY}

This paragraph summarizes the main findings of the study. In terms of the involvement and role of higher education institutes in co-creation within the public services innovation ecosystems, the central findings relate to the following themes: 1) universities of applied sciences as a hub of innovative knowledge community, 2) need for "an innovation unit" in a public organisation, and 3) participants in public sector innovation ecosystems. Finally, figure 2 outlines based on this study the actors in the public sector innovation ecosystem and their mutual relationships.

\section{(1) A hub of innovative knowledge community.}

The public services innovation ecosystems can be regarded as innovative knowledge communities with the aim of making a conscious and systematic effort to develop socially shared objects in the community and to go beyond previous knowledge. Co-creation takes place in a group representing different views and skills, which focuses on the long-term design and implementation of a specific idea or service. Essential to this is not only individual learning or social and cultural interaction, but interaction and development through the design of a shared idea or service. A group representing different competencies works to promote and develop a common and shared object (e.g. service ideas, public service concepts).

Higher education institutions are seen as playing an important role in the networked co-creation of public services. The role of university of applied sciences in public sector innovation ecosystems can be seen as a hub of innovative knowledge communities. New innovation ecosystems have created demands for the flexible combination of working life needs and academic research results. Thus, orchestrating and managing the creation and dissemination of knowledge during the co-creation process integrates the three tasks of the university of applied sciences; education, R\&D and regional development.

\section{(2) Need for "an innovation unit" in a public organisation.}

Public organizations (e.g., cities and municipalities) tend to be large, hierarchical, and fragmented. One of the challenges of co-creation is often the flow of information between the public organization 
and external actors as well as within the public organization. For external actors, reaching the right branch and actors in the public sector is challenging. The organizational culture and structures within public organizations are still, in part, ones that may prevent the adaptation of new ideas, skills, action models and enthusiasm into the public organizations. As a solution, it was proposed to establish an organization-wide innovation unit, which would be responsible for relations with higher education institutes and other stakeholders, as well as managing information related to innovation activities. The innovation unit receives new development challenges from within the organization and forwards the service concepts created as a result of co-development to the right parties in the organization.

\section{(3) Participants in public sector innovation ecosystems.}

Co-creation has become one of the most significant approaches in the design and delivery of public services worldwide. Co-creation brings together citizens, companies, third-sector actors, higher education institutes (e.g. researchers, teachers and students) and public-sector actors to identify needs and solve problems associated with the public service ecosystem and services. An essential element in co-creation is that the participants can surpass their own limits by collaboration and examine the current issue from alternative perspectives. As a social process co-creation aims at achieving consensus among participants with different backgrounds, competences, and interests. New and innovative solutions to public sector challenges can be found when different perspectives are combined.

Figure 2 illustrates and summarizes the identified actors in the public sector innovation ecosystem and their mutual relationships based on this study.

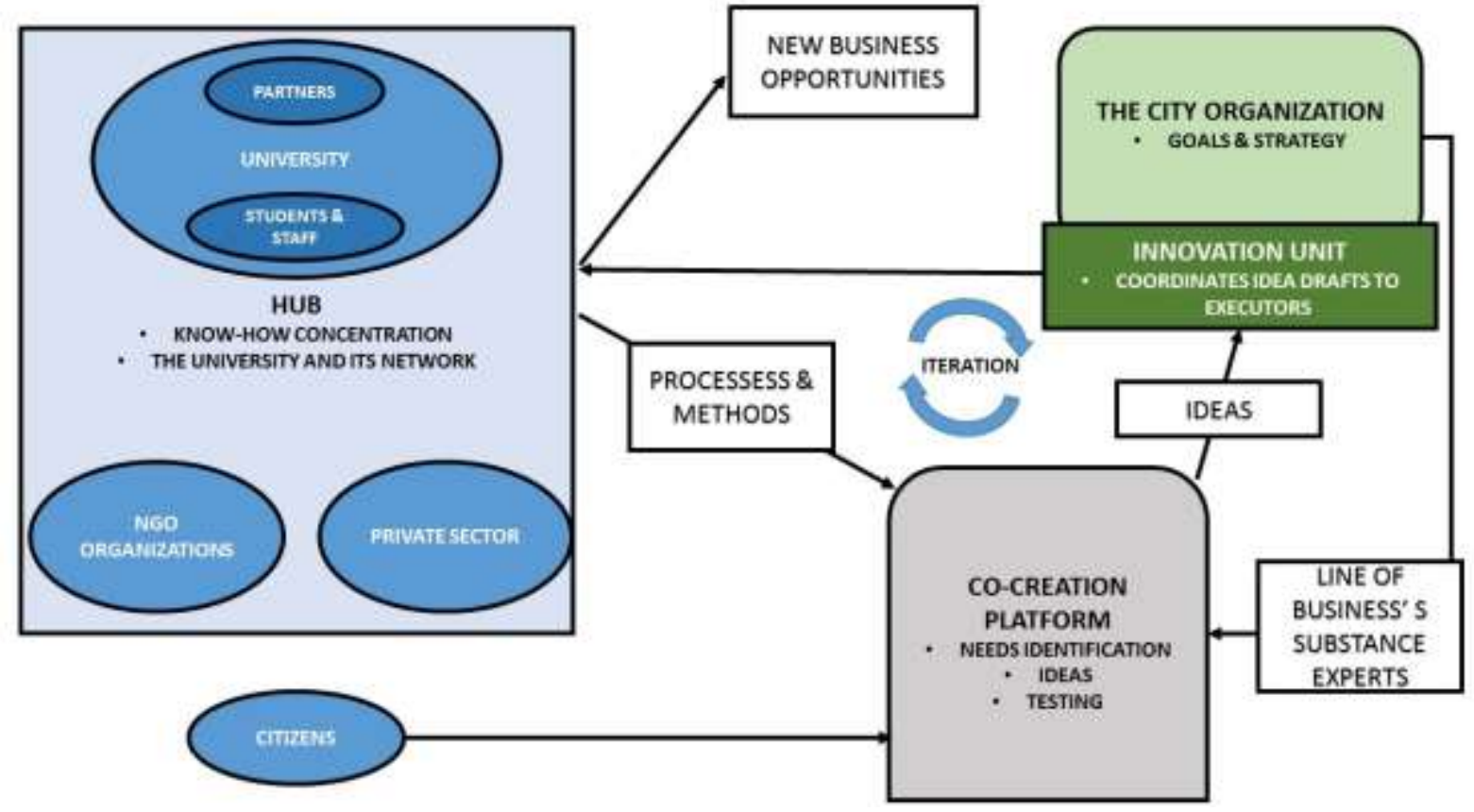

Figure 2. An outline of the actors in the public sector innovation ecosystem (visualization: Lassi Tähtinen)

\section{DISCUSSION}

The results indicate that higher education institutes have a significant role in the public innovation ecosystem as drivers of national competitiveness. In addition to their educational mission, higher education institutes promote regional development by maintaining networks and orchestrating innovation activities in the ecosystems.

However, public sector innovation is still very fragmented in nature with weak links between possible co-creators. Without systematic development efforts and shared rules, co-creation will remain at the level of individual projects and will not become an established operating model for creating and 
producing public services. Co-creation also challenges the traditional decision-making processes of the public sector, which involve politicians and industry leaders. It could be beneficial to ignite a debate about creating a new, more open governance model that supports co-creation.

In addition, at the heart of development based on the platform economy is digitalisation, the application of which permeates not only all industries but also urban services and the everyday life of citizens. Digital platforms would make it easier to combine relevant knowledge, ideas and resources. The adaptation of co-creation into the public innovation ecosystems is still at a very early stage of maturity.

\section{ACKNOWLEDGEMENTS}

This work was part of the European Union's Seventh Programme for research, technological development and demonstration under grant agreement No 645845 in the "WeLive - A neW concept of pubLic administration based on citizen co-created mobile urban services" project.

\section{REFERENCES}

[1] Ministry of Education and Culture (2014) Universities of Applied Sciences Act. Finlex. https://finlex.fi/en/laki/kaannokset/2014/20140932

[2] OECD (2015). The Innovation Imperative in the Public Sector: Setting an Agenda for Action. Paris: OECD Publishing. http://dx.doi.org/10.1787/9789264236561-en.

[3] Baregheh, A., Rowley, J., \& Sambrook, S. (2009). Towards a multidisciplinary definition of innovation. Management Decision, 47(8), 1323-1339.

[4] Fuglsang, L. (2012). Bricolage as a way to make use of input from users. In J. Sundbo \& M. Toivonen (Eds.), User-Based Innovation in Services (pp. 25). Cheltenham UK: Edward Elgar.

[5] Jäppinen, T. (2015). How to manage a service innovation process in the public sector: from codesign to co-production. In The Handbook of Service Innovation (pp. 707-726). Springer, London.

[6] Demircioglu, M. A., \& Audretsch, D. B. (2017). Conditions for innovation in public sector organizations. Research Policy, 46(9), 1681-1691.

[7] Windrum, P., \& Koch, P. M. (Eds.). (2008). Innovation in public sector services: entrepreneurship, creativity and management. Edward Elgar Publishing.

[8] Langergaard, L.L. (2011) 'Understanding of 'users' and 'innovation' in public sector context', in Sundbo, J. and Toivonen, M. (Eds.): User-based Innovation in Services, pp.203-226, Edward Elgar Publishing Limited, Cheltenham, UK.

[9] Hartley, J., Sørensen, E., \& Torfing, J. (2013). Collaborative innovation: A viable alternative to market competition and organizational entrepreneurship. Public Administration Review, 73(6), 821-830.

[10] Bryson, J., Sancino, A., Benington, J., \& Sørensen, E. (2017). Towards a multi-actor theory of public value co-creation. Public Management Review, 19(5), 640-654.

[11] Pollitt, C., \& Bouckaert, G. (2017). Public Management Reform: A Comparative Analysis-Into the Age of Austerity. Oxford University Press.

[12] Akaka, M. A., Vargo, S. L., \& Lusch, R. F. (2013). The complexity of context: A service ecosystems approach for international marketing. Journal of International Marketing, 21(4), 1 20.

[13] Pinho, N., Beirão, G., Patrício, L., \& P. Fisk, R. (2014). Understanding value co-creation in complex services with many actors. Journal of Service Management, 25(4), 470-493.

[14] Trischler, J., \& Charles, M. (2019). The application of a service ecosystems lens to public policy analysis and design: exploring the frontiers. Journal of Public Policy \& Marketing, 38(1), 19-35.

[15] Petrescu, M. (2019). From marketing to public value: towards a theory of public service ecosystems. Public Management Review, 1-20. 
[16] Osborne, S. P. (2018). From public service-dominant logic to public service logic: are public service organizations capable of co-production and value co-creation?.

[17] Borins, S. (2014). The Persistence of Innovation in Government. Washington DC: Brookings Institution Press.

[18] Sørensen, E., \& Torfing, J. (eds.). (2016). Theories of Democratic Network Governance. Springer.

[19] Huppé, G. A., Creech, H., \& Knoblauch, D. (2012). The frontiers of Networked Governance. Winnipeg, Manitoba, Canada: International Institute for Sustainable Development.

[20] Emerson, K., \& Nabatchi, T. (2015). Collaborative Governance Regimes. Georgetown University Press.

[21] Torfing, J. (2018). Collaborative innovation in the public sector: the argument. Public Management Review, 1-11.

[22] Markkula, M., \& Kune, H (2015). From Research to Reality in Orchestrating Regional Innovation Ecosystems. Otava. Finland

[23] Raunio, M., Nordling, J., Saarinen, J. P., Ketola, T., \& Ruokonen, H. (2018). Avoin innovaatioalusta kaupunkikehittämisen lähestymistapana. Käsikirja kehittäjille 2.0.

[24] Vaajakallio, K. (2012). Design games as a tool, a mindset and a structure. Aalto University.

[25] Patton, M.Q. (2002). Qualitative Research \& Evaluation Methods (3rd ed.). London: Sage. 